\title{
An assessment of the National Transport Master Plan (NATMAP) 2050 for South Africa and its implementation framework
}

\author{
C. B. Schoeman \\ School for Geo and Spatial Sciences, \\ North West University, South Africa
}

\begin{abstract}
NATMAP (2050) was approved by the South African Government in 2011. The focus of the project is to ensure that by 2050 transportation development will meet the needs of freight and passenger customers; to ensure accessible, affordable, safe, frequent, high quality, reliable, efficient and seamless transport operations and infrastructure provision and development.

The project makes provision for a process of continued upgrading, innovative, flexible, economically and environmentally sustainable transportation that will support and enable government strategies, growth, development, redistribution, employment and social integration within the national spatial system. The project endeavours to address this distorted land use and transportation situation provincially and nationally. The research methodology includes an assessment of the Action Agenda as included in the NATMAP (2050) source documents and its supporting methodologies and strategic approaches.

The research results are reported on from a sustainable transportation and strategic perspective. It will include an in depth analysis of the strategies formulated, prioritization model, implementation projects and strategic development programme. The improvement of special intervention transportation development focuses is included as to enhance sustainable transport development within all spatial systems.

Keywords: strategic transportation planning, land use and transportation integration, project prioritisation.
\end{abstract}




\section{Introduction}

The Transport Lekgotla (Convention) held on 08-09 April 2005 resolved that an “Integrated National Transport Plan” for South Africa should be developed. The then Integrated National Transport Plan (INTP) was later referred to the National Transport Master Plan (NATMAP). In the development of NATMAP (2050), it was necessary to identify and crystallise existing perennial problems and those which resulted from alternative socio-economic development strategies and to indicate how best these may be formulated, prioritised and implemented [1].

NATMAP (2050) goal is to develop a dynamic; long term; and sustainable land use/multi-modal transportation systems framework for the development of networks infrastructure facilities; interchange termini facilities and service delivery. The focus is that NATMAP (2050) should be demand responsive to national/provincial/district and /or any socio-economic growth strategy, and/or any sectoral integrated spatial development plan [1]. The application of strategic planning to transportation plans and problems are not n new phenomenon and/or development in long term planning.

\section{Theory and processes related to strategic planning}

Strategic planning according to Dressler [2] serves a variety of purposes in organization:

- $\quad$ Clearly define the purpose of the organization and to establish realistic goals and objectives consistent with that mission in a defined time frame within the organization's capacity for implementation.

- Communicate those goals and objectives to the organization's constituents.

- Develop a sense of ownership of the plan.

- $\quad$ Ensure the most effective use is made of the organization's resources by focusing the resources on the key priorities.

- $\quad$ Provide a base from which progress can be measured and establish a mechanism for informed change when needed.

- Bring together of everyone's best and most reasoned efforts have important value in building a consensus about where an organization is going[2]

A similar approach is contained in Haberberg and Rieple [3]. In context to the focus of NATMAP (2050) strategic transportation planning also involves regional development theory [4 and 5]. However, the complexities involved in strategic transportation planning is best described in the term CLIOS (Complex, large-scale, integrated, open systems) [6]. The application of tools such as multicriteria analysis in this regard is thus of importance as will become clear hereunder. 


\section{Policy and legislative framework guiding strategy formulation}

The transformation and development of transport (land transport) and spatial planning in South Africa within all spheres of government is being guided through the policy and legislative framework timeline as shown in Table 1 (A detailed discussion is contained in Schoeman in UT 2012) [7]. For the purposes of this paper it should be noted that NATMAP (2050) only deals with the national and provincial spatial systems and not with the municipal sphere of government and its related spatial systems (rural, towns and metropolitan areas).

Table 1: Transformation of core policies and legislative framework for transport planning and spatial development.

\begin{tabular}{|c|c|}
\hline Policy framework & Legislative framework \\
\hline $\begin{array}{l}\text { White Paper on National Transport Policy } \\
\text { (1996) }\end{array}$ & Urban Transport Act (Act 78 of 1977) \\
\hline Moving South Africa (Vision 2020) (1999) & Road Transport Act (Act 74 of 1977) \\
\hline $\begin{array}{l}\text { White Paper on Spatial Planning and Land } \\
\text { Use Management (2001) }\end{array}$ & $\begin{array}{l}\text { Development Facilitation Act (Act } 67 \text { of } \\
\text { 1995) }\end{array}$ \\
\hline $\begin{array}{l}\text { National Spatial Development Perspective } \\
(2003)\end{array}$ & National Road Traffic Act (Act 93 of 1996) \\
\hline $\begin{array}{l}\text { Rural Transport Strategy for South Africa } \\
(2003)\end{array}$ & \multirow[t]{2}{*}{$\begin{array}{l}\text { Constitution of the Republic of South Africa } \\
\text { (Act } 108 \text { of 1996) }\end{array}$} \\
\hline National Freight Logistics Strategy (2005) & \\
\hline $\begin{array}{l}\text { National Spatial Development Perspective } \\
(2006)\end{array}$ & $\begin{array}{l}\text { National Transport Interim Arrangements } \\
\text { Act (Act } 45 \text { of 1998) }\end{array}$ \\
\hline $\begin{array}{l}\text { Accelerated and Shared Growth-South } \\
\text { Africa (ASGISA) (2006) }\end{array}$ & $\begin{array}{l}\text { Cross Border Road Transport Act (Act } 4 \text { of } \\
\text { 1998) }\end{array}$ \\
\hline $\begin{array}{l}\text { Draft minimum requirements for the } \\
\text { preparation of integrated transport plans } \\
\text { (ITP) (2007) }\end{array}$ & $\begin{array}{l}\text { Transport Appeal Tribunal Act (At } 39 \text { of } \\
\text { 1998) }\end{array}$ \\
\hline $\begin{array}{l}\text { National Land Transport Strategic } \\
\text { Framework (2006-2011) (2002) (Draft) }\end{array}$ & Road Traffic Act (Act 29 of 1998) \\
\hline $\begin{array}{l}\text { Rural Transport Strategy for South Africa } \\
(2003) \text {. }\end{array}$ & Municipal Structures Act (Act 117 of 1998) \\
\hline $\begin{array}{l}\text { Sustainable Human Settlement Planning } \\
\text { (2009); Human Settlement Atlas (2009) }\end{array}$ & $\begin{array}{l}\text { National Land Transport Transition Act } \\
\text { (Act } 22 \text { of 2000) }\end{array}$ \\
\hline National Housing Code, 2009. & Municipal Systems Act, (Act 32 of 2000) \\
\hline National Growth Plan (2009) & $\begin{array}{l}\text { National Land Transport Act (Act } 5 \text { of } \\
\text { 2009) }\end{array}$ \\
\hline $\begin{array}{l}\text { National Transport Master Plan } 2050 \\
\text { (NATMAP 2050) (2011) }\end{array}$ & $\begin{array}{l}\text { R. } 1208 \text { National Land Transport Act } \\
\text { (5/2009): National Land Transport } \\
\text { Regulations. }\end{array}$ \\
\hline $\begin{array}{l}\text { National Planning Commission (NPC) } \\
\text { Diagnostic Report (2011) }\end{array}$ & $\begin{array}{l}\text { R. } 877 \text { National Land Transport Act } \\
\text { (5/2009): National Land Transport } \\
\text { Regulations on Contracting for Public } \\
\text { Transport Services. }\end{array}$ \\
\hline $\begin{array}{l}\text { National Planning Commission (NPC): } \\
\text { National Development Plan for } 2030 \text { (201 }\end{array}$ & $\begin{array}{l}\text { Spatial Planning and Land Use Management } \\
\text { Bill (2012) }\end{array}$ \\
\hline
\end{tabular}

Source: Own construction, 2013. 


\section{Associated transportation and development related problems}

- Transportation systems within the national and provincial spatial systems are characterised by and riddled with problems both within transport modes themselves and between these modes and a lack of integration.

- Some components of transportation systems are neither demand responsive nor cost effective.

- Land use and transportation planning are poorly integrated. Transportation is slow and inadequate to respond to the needs of committed and/or proposed land use and related market needs and developments.

- Transportation is not embracing its optimal role in stimulating economic and spatial development within all spatial systems.

- $\quad$ Poor land use and transportation integration planning is aggravated by sporadic unplanned land use within major corridors and within and outside urban areas.

- There is poor accessibility in rural areas notwithstanding rural transportation strategies.

- Financing of transportation systems, infrastructure facilities, rolling stock, and equipment is competing with other public services sectors, with transportation on the lowest priority [8].

\section{NATMAP project methodology and the purpose of the paper}

The NATMAP (2050) project consists of four phases:

- The Status quo, Phase 1, provides an overview of current transportation systems, land use, demographic and socio economic and related conditions [1].

- The Analysis, Phase 2, assess the status quo information. This phase represents the quantitative analysis of different land use and transportation integration and development scenarios [9].

- $\quad$ Forward Planning, Phase 3, contains not "what is, or what will be, but simply what ought to be”. Given a clear understanding of the current situation and the impacts on the transportation sector and communities as derived from the previous two phases, this phase is about the alternative strategies that can be followed in the future and consequently also the policies, decisions and strategies to be addressed [10].

- The Agenda for Action, Phase 4, takes the alternative strategies to its final stage, focusing on an action agenda (project plan) for implementation [11].

Figure 1 shows the outline of the NATMAP process and methodology. 




Figure 1: Outline of the NATMAP process and methodology based on its core focuses. (Source: NATMAP, Phase 4, 2011.)

The detail of the outcome of Phases 1 to 3 of NATMAP (2050) will not be discussed in this paper as the purpose of the paper is to assess only Phase 4: Agenda for Action [8, 11] related to institutional, policy, programmes, project, timeframes and project costs. However, it is imperative that cross references will be made to the content of the other phases of the project where applicable [1, $9,10]$.

\section{Terms of reference of NATMAP (2050) Phase 4}

The terms of reference for the Agenda for Action (Phase 4) include the following core considerations:

- $\quad$ Policy: review of existing transportation policies, rules, regulations, and related guiding principles (Refer to Table 1 above).

- Development of schedules: development of a National and Provincial goal achievement matrix (GAM); prioritization of related policies, institutional matters, infrastructure facilities, and components as deduced from all of the preceding Phases of NATMAP (2050). All project components to be procured on a phased and incremental basis. Development of strategic scenarios for transportation focuses in 
development and investment. Ensure compatibility with "Five Year Development Plans”.

- $\quad$ Critical projects-implementation programme: Design of a critical path methodology for all project contained in the GAM. Propose the need for project inception and preliminary designs; detailed feasibility project plans; detailed project preparation; formulation of project implementation documentation; formulation of a monitoring system and evaluation approach. Proposals in this regard are subject to stakeholder engagement [11].

\section{Methodology and action plan for NATMAP (2050) Phase 4}

The methodology followed in the formulation of the Agenda for Action is illustrated in Figure 2.

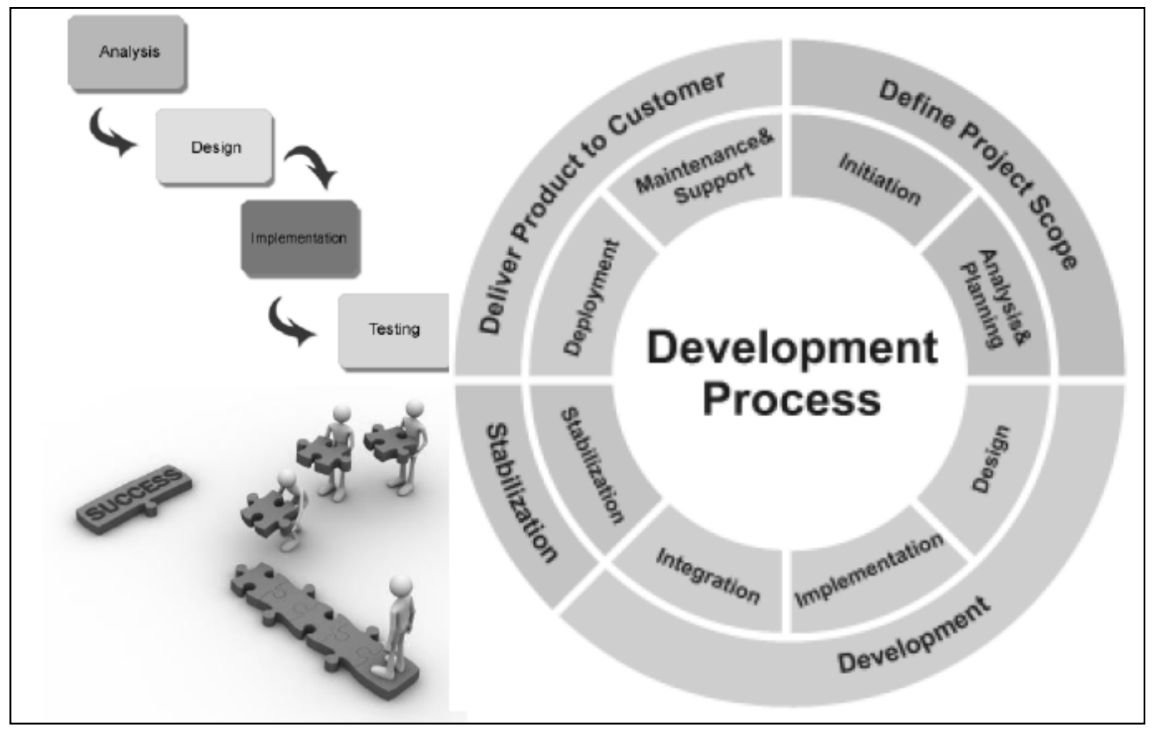

Figure 2: Methodology and action plan development process. (Source: NATMAP (2050), Phase 4, 2011.)

Development of the Action Plan is based on the following approaches, processes and input:

- Policy, goals and objectives for NATMAP (2050). [1, 8-11]

- Development of a decision-making mechanism in the form of a goal achievement matrix (GAM). The GAM technique consists of a tool in which project are prioritized based on specific preferred assessment of development impact, estimated project costs and timeframes [8, 11]. 
- $\quad$ The GAM is applied per provincial spatial system. National projects are identified where projects extend physically across provincial or national boundaries.

- $\quad$ Based on the outcome of Phase 1 to 3 of NATMAP (2050) the GAM is applied by spatial entity as well as mode of transport in terms of the GAM evaluation mechanism.

- Transformation of the identified transportation developmental needs and focuses into benchmarks or standards as to attain a comprehensive transportation (sustainable?) systems approach as envisaged for 2050 that forms the basis for the NATMAP project.

- Agenda for Action is then transformed into project inclusive timeframes and project costs as described above.

- Identification of critical projects in terms of priority and project size (mega-projects) that will have a long lead time over longer time frames supported by projects classified to be critical for implementation over the next five (5) years [11].

In NATMAP (2050) Phase 4 [11] it is stated that the Goal Achievement Matrix (GAM) applies an adopted internationally accepted Multi-Criteria Analysis (MCA) [8, 11 and 12] and Pairwise Comparison Matrix (PWC) [13] methodologies to assess and accordingly analyse and prioritise identified NATMAP (2050) projects that are discussed in detail. The GAM technique also incorporates a strategic stakeholder participation process whereby participants are requested to assist with the weighting of the NATMAP (2050) Goals and Objectives; since they form the basis for assessing, prioritizing and implementation of projects $[4,5]$. The procedure of the GAM model is illustrated in Figure 3.

\section{Blue print for the development of transportation in terms of NATMAP (2050)}

Strategic planning processes centres specifically in the case of NATMAP (2050) around project components such as the status quo position (facts and figures) (Phase 1) [1]; assessment and evaluation of alternative options (Phase 2) [9] and forward and long term planning approaches (Phase 3) [10]. The final step in strategic planning is to define and listing of potential projects to be implemented (Phase 4) [8, 11].

The following strategic planning regime is utilized in the Agenda for Action as contained in NATMAP (2050) Phase 4:

- Blue print foundations: linkages to stated vision, mission, policies, goals, objectives and strategies. Determination of main drivers for a changed transportation development scenario supported by the components and role of the envisaged transportation system.

- $\quad$ Benchmark and standards: The development of a public transportation system versus private vehicle usage; future development of freight 
transportation system; future road and rail network and future aviation, maritime system inclusive of ports and pipelines.

- $\quad$ Strategic development programme: Identified projects, description and priorities; programmes, cost and budgets; critical and mega projects [8 and 11].



Figure 3: Explanation of the GAM model. (Source: NATMAP (2050), Phase 4, 2011.)

The blue print foundations are being supported by main drivers for a changed future transportation system inclusive of uncontrollable and external impacts; resistance to change; symptomatic impacts due to stagnant, backlogs that have developed over a long period of time and that will require extra-ordinary measures and resources to normalize. Focus is to address the main drivers and not the symptoms itself [11].

The strategic interventions for the blue print foundations include inter alia the following focuses:

- $\quad$ Modal shift: A major shift from road to rail. Application of economic and technical regulations for specific traffic modes. Road transport should not be the only choice in freight transport practices. Sufficient, effective acceptable rail and air transport infrastructure is to be developed. 
- $\quad$ Public transport: Promotion of public transport with emphasis on mass modes, higher capacity and more energy efficient vehicles with less carbon emissions.

- Equitable transport: Application of a "wall to wall” service delivery network to ensure equitable and fair service provision. Promotion of modal choice options.

- $\quad$ Alternative transportation networks: Acceptable and efficient alternative transportation networks and systems need to be provided. Alternative measures to enhance a more acceptable modal balance to be introduced.

- Infrastructure development and transportation system technology: High and medium speed rail systems to be introduced with preference to standard gauge; road network enhancement to focus on capacity and quality improvements than adding new roads to the network; traffic demand management and high price strategies to be implemented to ensure shift of road to rail; BRT and other bus systems to be introduced; corridor development parallel to bus and rail systems may be justified based on modal integration; introduction and promotion of low capacity and less energy efficient private motor vehicles; promotion of use of higher capacity vehicles; air and sea port developments to focus on capacity expansions and equipment and handling enhancements; construction of new international airports within certain metropolitan areas; harbour capacity developments as demand dictates and upgrading of pipelines capacity based on multi-functional pipelines from harbours to inland destinations.

- National transportation institutional and management arrangements: Creation of a new rail agency (Rail Infrastructure Development Agency) similar to SANRAL; restructuring of current transportation government institutions; implementation of regulatory measures to promote shift from road to rail $[8,11]$.

\section{Main drivers for a changed future transportation system}

The following forms an indication of the main drivers (influences) for a changed future transportation system:

- $\quad$ Systematic economic growth and development.

- Normalization of the RSA society and political environment.

- Demographic restructuring.

- Market preferences and competitive environment.

- Continuous spatial and land use developments.

- $\quad$ Focussed and defined corridor developments.

- Global energy and environmental challenges and developments.

- Technological innovations and international best practices.

- $\quad$ RSA's regional connectivity. 
- Systematic let-go of discipline, reducing standards and neglect of responsibilities.

- $\quad$ Changing transportation policy and governance environment [11].

\section{Strategic transportation investment and expenditure summary}

Based on the abovementioned approach and strategic focuses and outcomes the GAM assessment related transportation project prioritisation was applied. The following contains a broad summary that is indicative of the investment and capital expenditure to be made in order to meet the vision, mission, goals, objectives and programmes based on the approach as contained in NATMAP (2050):

- $\quad$ Total value of NATMAP (2050) projects is R751.739 billion ( $\$ 88.4399$ billion) over a 40 year period.

- The envisaged capital expenditure programme includes:

$>19 \%$ or R144.375 billion ( $\$ 16.983$ billion) in the first five (5) years between 2010 and 2015.

$>45 \%$ or R335.792 billion (\$39.5049 billion) during 2015 to 2030.

> 36\% or R271.517 billion (\$31.9495 billion) during 2030 to 2050.

- The distribution of highest total cost by transportation category (service) is as follows: rail infrastructure R326.5 billion ( $\$ 38.4118$ billion) or $43 \%$ followed by road infrastructure R202.0 billion ( $\$ 23.7647$ billion) or $27 \%$ of the estimated capital investment required.

- Upgrading and development of the passenger rail projects will require and investment of R191.1 billion ( $\$ 22.4824$ billion) or 25\%. In terms of ranking it is followed by freight rail infrastructure with R135.4 billion ( $\$ 15.9294)$ or $18 \%$; national roads R122.8 billion ( $\$ 14.4471$ billion) or $16 \%$; harbours and airports R92.0 billion each ( $\$ 10.8235$ billion) or $12 \%$ each and other roads R78.7 billion ( $\$ 0.2588$ billion) or $10 \%$ of the total investment expenditure required.

- Provincial infrastructure projects represents some $60 \%$ of the total investment costs whilst national projects representing some $39 \%$. Financial Institutional and Management represents less than $1 \%$ of the total costs (R709.0 million or $\$ 83.4118$ million) [4].

Provision on organizational and management level also needs to be made for the formation of the following transportation related institutions:

$>$ Department of Transport: Multi Model Policy Forum.

$>$ Transport Investment Clearing House.

$>$ Transport Economic Regulator.

$>$ Road Weight Distance Charging Agency [8, 11]. 


\section{Conclusions}

From the assessment of the NATMAP (2050) (Phase 4) Agenda for Action in context to the title of this paper, the following conclusions can be drawn:

- If the project is viewed in its totality, it provides a holistic and integrated analysis, synthesis and strategic planning for promoting sustainable transportation integration, modal development, transportation development and most importantly the integration of land use and transportation.

- A short coming in NATMAP (2050) is the lack of stakeholder participation in context to the formulation process and to disseminate the strategic planning to all stakeholders. This process may lead to certain amendments in the transportation, developmental and land use interventions as formulated. The application of trans-disciplinary approaches as formulated by Fry in 2007 [14] should be followed.

- From a process point of view the envisaged implementation framework pivots around the implementation on feasibility studies, preliminary and final designs, budgetary provisions and accessing of funding sources with potential funding stakeholders and partners.

- Although the project was approved by the Department of Transport and the Cabinet in 2011, the content still needs to be subject to a process of stakeholder and public participation before implementation. After completion of this process, the draft documents related to NATMAP (2050) Phase 1 to Phase 5 may need review or reprioritization.

- Development of sustainable transportation key performance indicators (STKPI's) for all modes of transport and transportation related infrastructure as identified in the Agenda for Action of NATMAP (2050), needs to be undertaken and implemented as to ensure optimal project management and accountability.

- A structure for the on-going monitoring of the outcomes of the Agenda for Action (STKPI's) should be implemented in order to ensure sustainability in project planning and implementation through a process of continued intervention, coordination and management.

- The form and format of the new transportation agencies will have to be investigated, legally instituted and operationalized after a thorough process of stakeholder participation.

\section{References}

[1] Department of Transport: NATMAP Phase 1: Consolidated Status Quo Report (inclusive of Provincial Reports) (2008).

[2] Dressler. S. Strategy, Organisation and Performance: From Basics to Best Practices. Universal Publishers. Boca Ralton Florida (2004). 
[3] Haberberg, A. and Rieple, A., Strategic Management: Theory and application. Oxford University Press. pp. 5-92 (2007).

[4] Nijkamp, P. and Abreu, M., Regional Development Theory. PN218MAEOLSS. VU Netherlands. Amsterdam. pp. 1-12 (2009).

[5] Nijkamp, P. Infrastructure and regional development: A multi-dimensional policy analysis. In: Empirical Economics, Vol. 11, Issue 1. pp. 1-21 (1986).

[6] Sussman, J.M. and Sgouridis, S., ESD Symposium: Regional Strategic Transportation Planning as a CLIOS. Massachusetts Institute of Technology, pp. 2-20 (2004).

[7] Schoeman, C.B., Transformation within Transportation Planning in South Africa: Implications for the implementation of the National Transport Master Plan (NATMAP) of 2011. Urban Transport XVIII Conference. Acaruna. Spain. (2012) (To be published in 2013).

[8] Department of Transport: NATMAP National Report Executive Summary (2010).

[9] Department of Transport: NATMAP Phase 2: Consolidated Analysis (inclusive of Provincial Reports) (2009).

[10] Department of Transport: NATMAP Phase 3: Consolidated Forward Planning (inclusive of Provincial Reports) (2009).

[11] Department of Transport: NATMAP Phase 4: Consolidated Agenda for Action Report (inclusive of Provincial Reports) (2011).

[12] Source Book 2: Evaluating Socio Economic Development. Methods and Techniques. Multi-Criteria Analysis pp. 1-12 (2009).

[13] Saaty, T.L., Decision making with the analytic hierarchy process. Int. J. Services Sciences: Vol. 1, No. 1. pp. 83-98. (2008).

[14] Fry, G., Tress, B. and Tress, G.: Integrative landscape research: facts and challenges. In: Wu, J. and Hobbs, R.J. (eds). Key topics in Landscape Ecology. New York. Cambridge University Press. (2007). 